\title{
'Canst paint a doleful cry?': Promotion and Performance in the Spanish Tragedy Title-Page Illustration
}

The Spanish Tragedy ${ }^{1}$ was one of the first and most successful dramas to cross over from staged performance to printed text in early modern England. Between $1592^{2}$ and 1597 it was performed twenty-nine times, third behind The Jew of Malta and The Wise Man of West Chester; 3 the play was regularly revived at the Rose Theatre and then the Fortune Theatre from 1597 to 1642.4 The Spanish Tragedy also ran through twelve editions between 1592 and 1633; its constant availability in print throughout this period would have made it attractive to acting companies as a popular element of their touring repertoire as well as their London offerings. ${ }^{5}$ The continuing popularity of The Spanish Tragedy on stage and in print may have been due in part to a series of textual updates and emendations that kept it fresh for audiences and readers. In 1601 and 1602, for example, Philip Henslowe commissioned four significant additions to the text that were designed for performance but which made their way into ensuing print editions. ${ }^{6}$ Beginning with the seventh edition in 1615 , the title page was also augmented with a woodcut scene from the play (figure 1). The woodcut illustration was affixed to the next four editions. ${ }^{7}$ This illustration has been the source of much debate among theatre historians in terms of its relationship to the play. Three elements form the crux of the discussion about possible documentary evidence: the communication benefit derived from incorporating the woodcut in the title page, the composition of the visual sequence, and the design of the device from which Horatio is hanging in the image. All three of these elements raise important questions about the strength of the illustration as an emblem for the play in the early modern English marketplace.

Theatre historians have been generally disinclined to pursue a graphical line of inquiry in terms of illustrated title pages of early modern play-texts and have been hesitant to identify woodcuts and engravings as documentary evidence of theatrical performance or practice. The controversy regarding 


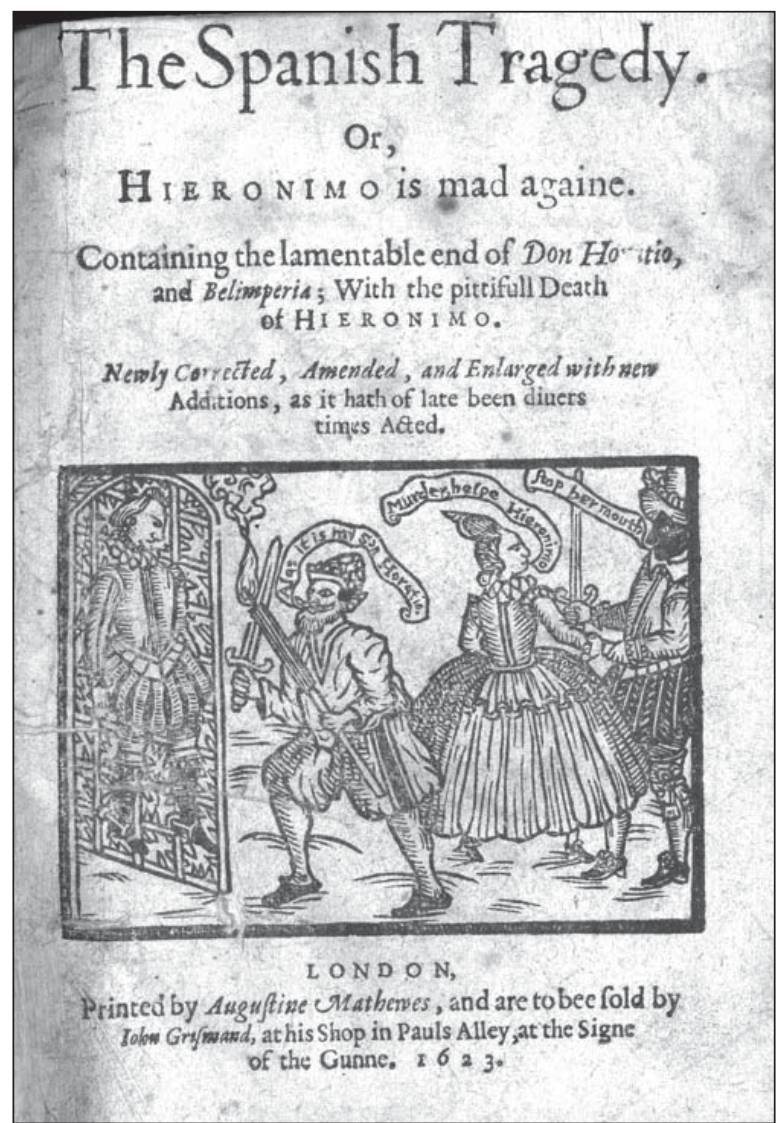

Fig. 1. The Spanish Tragedie or, Hieronimo is mad againe, Containing the lamentable end of Don Horatio, and Belimperia; With the pittifull Death of Hieronimo. London, 1623. The Newberry Library, Chicago. Digital image.

the Spanish Tragedy illustration derives more specifically from comparison of the woodcut illustration to modern editions of the play, in which the imposition of scene breaks weakens the connection between text and visual interpretation. The multimodal nature of the illustrations, however, provides a singular opportunity for scholars to examine the representational value of such title-page woodcut illustrations. In this essay, I will approach this artefact in two ways: first, in its relation to the sequence of action in the 1623 edition that it appears to represent; second, as an example of visual rhetoric, which is intentional, persuasive, and important. ${ }^{8}$ The Spanish Tragedy 
woodcut offers us a case study demonstrating how title-page imagery and its circulation can contribute to our understanding of theatre culture in early modern London, and addresses questions of intention, production, and distribution. Through presentation of a moment of spectacular stage violence, the title-page woodcut offers an intriguing perspective on how the relatively new genre of printed drama could sustain the attention of the early modern book-buying public. In the process we may reveal valuable information about how such a published artefact could have served to symbolize the play as a marketing tool in circulation for almost twenty years.

Scholars have been ambivalent about the quality and usefulness of the Spanish Tragedy illustration. Alfred W. Pollard called it 'mealy' and exclaimed that 'the design has not many artistic merits; but in point of faithfulness it is probably all that could be desired'. ${ }^{9}$ Edward Hodnett singled out the title pages of The Spanish Tragedy and Doctor Faustus as 'primitive' but valuable visual resources in the history of book illustration: 'These woodcuts are technically naive, but they are penetrating illustrations, for they get at the heart of the plays. ${ }^{10}$ Hodnett also makes a case for attempting to assess the value of such woodcuts without imposing modern prejudices upon early modern English drafting practices: 'Passing remarks by literary scholars about illustrations sometimes betray unbecoming ignorance of technical processes and the conditions attending their use. Perhaps the commonest example is the automatic use of the adjective "crude" whenever a woodcut in an early modern English book is mentioned'. ${ }^{11}$ If we are to properly examine illustrations such as that on the Spanish Tragedy title page, we must put modern aesthetic preconceptions aside and focus on the promotional, memorial, representational, narrative, and rhetorical functions of the image.

The publication of popular plays in England began in earnest in the early 1590s. If surviving play-texts are representative, the incorporation of woodcut illustrations addressing some aspect of the play — whether scene or portrait - came years later. Aside from the allegorical scene on the 1590 edition of The Three Lords and Three Ladies of London, the next instance of an illustrated play-text title page occurred in 1605 with If You Know Not Me You Know Nobodie. ${ }^{12}$ Forming conclusions about the relationship between printed plays and illustration in the first half of the seventeenth century is difficult because publishing data does not yield easily recognizable patterns. ${ }^{13}$ Of 738 editions published between 1605 and 1660, ninety-two featured a title-page illustration meant to invoke the play. Of these fifty-seven were unique plays. Only eleven plays show reuse of an illustration from one edition to the next. 
But of these, all but two continued to offer an edition with the same - or copied $^{14}$ — illustration more than fifteen years later. The Spanish Tragedy was one of these.

The continued incorporation of illustrations into play-text title pages suggests that publishers recognized the marketing value inherent in presenting a hypermedial message to their customers, wherein the relationship between text and image is dialogic. ${ }^{15}$ The placement of such an illustration would have drawn the purchaser's attention and enhanced the play-text's communication value, especially when one considers the number of competing volumes on display in the bookselling centres of St Paul's Churchyard and Smithfield Market. The illustrated title pages would have invoked a participatory relationship that attached the characters in the play to a range of viewers. Kress and Van Leeuwen identify two types of participants in images: represented participants, the people, the places, and things depicted in images; and interactive participants, the people who communicate with each other through images, the producers, and the viewers of images. ${ }^{16}$ These illustrated title pages would have been prominently displayed in booksellers' shops, both as the covers of the books for sale ${ }^{17}$ and as posters promoting the play-texts' availability. ${ }^{18}$ The represented participants will be examined in detail below, but I stress here that the interactive participants in this exchange included not only the bookseller and the potential buyer, but also the publishers, printers, and artists. Kress and Van Leeuwen also assert that these participants could engage in three types of relations: those between represented participants; those between interactive and represented participants, wherein the emphasis lies with the interactive participants' attitudes toward the represented participants; and those between interactive participants, wherein participants impact one another through the use of images. ${ }^{19}$ The continued use of the Spanish Tragedy woodcut suggests that the relationship between the customer and the image was a successful one. Other publishers apparently recognized the value of the illustration as well: Henry Gosson attached it to a broadside ballad in 1620 that appears to have derived from the play. ${ }^{20}$ The initial success of this relationship seems to have also had long-range implications for publishers and printers, who would have had to make arrangements to store, reuse, and transfer the woodblock among printers. Not only was the woodblock lent out for Gosson's ballad, but also the publication arrangements changed as of the 1623 edition - Francis Grove bought the publishing rights from John White and Thomas Langley, and Augustine Mathewes 
took over as printer from William White — thus creating additional implications for the ownership of the woodblock.

The scene in the woodcut, featuring the murder of Horatio and Hieronimo's discovery of his dead son, would have resonated especially with two types of viewers: those who had seen a performance of the play and those who had heard about it. These interactive participants, whether they had first-hand experience of The Spanish Tragedy or were otherwise aware of its themes and narrative threads, would have been familiar with the dramatic action in the woodcut. This recognition would have served the playhouse as well as the printing house. Tiffany Stern believes such title pages provide a missing link to playbills promoting the plays in performance. As play-text covers in the bookseller's shop and as single-sheet flyers nailed to available posts and beams around London, these were advertisements imbued with significant cultural capital. They promoted the same work, only in different forms. Stern suggests that these promotional pages were more resonant for Londoners than the plays in performance or print: 'For many the bills were the nearest they would get to a play or a book, and the grounds on which they would build all their theories about what was going on inside the theater or inside the text'. ${ }^{21}$ This semiotic exchange between the interactive and represented participants therefore takes on added importance. The title page becomes the nexus of information: viewers bring to it their conceptions of the dramatic work and take away an important marketing message. The title page of The Spanish Tragedy not only offers the viewer direction about where they can buy the play-text but also presents a clear understanding of how they should connect with this complex play. The subtitle refers to Hieronimo's frustrated revenge — 'Hieronimo is mad againe' — completely ignoring the framing device of Don Andrea and Revenge. It also underscores that madness with a visual rationale that is not otherwise offered on the title page: Horatio's murder is seen, but not referred to in the subtitle. The evocative illustration on the title page of The Spanish Tragedy would help to further distinguish it from all the other title pages on display in the bookstalls and hanging from walls and posts.

Theatre historians have raised questions related to the composition of the illustration, struggling with the fact that in modern editions the action of the sequence in the image - Horatio's hanging, Bel-Imperia's kidnap, and Hieronimo's discovery of the body - takes place across two scenes, 2.4 and 2.5. Holger Schott Syme, perhaps influenced by this modern editorial arrangement, describes the sequence as 'two distinct but contiguous 
moments'. ${ }^{22}$ For some, the two-scene structure presented in one visual frame weakens the image as a potential artefact of performance. In addition, the non-linear representation of the characters, wherein the action unfolds from the margins to the centre rather than from left to right, requires a more focused approach to reading the action in the scene. In fact, the 'contiguous moments' from the play are actually sequential, a fact that is more in keeping with the speed of the unfurling of the action. As well, the 'centre/margin'23 layout of the illustration reveals significant information about early modern modes of visualization.

The 1623 edition of the play reveals, however, that there was no break in the performance between what we know as scenes 2.4 and 2.5. The action would have been performed as one ongoing sequence. This 'French scene' begins with the lovers Horatio and Bel-Imperia meeting in the arbour below Hieronimo's house. Bel-Imperia's brother Lorenzo, her would-be suitor Balthazar, and the servants Pedringano and Serberine interrupt the lovers. The marauders are masked and move swiftly to separate the heroic Horatio from the passionate Bel-Imperia. The attack comes so quickly and is carried out so savagely that Horatio cannot defend himself. His one line comes after the stage direction 'they hang him in the arbour' when he asks incredulously, 'What, will ye murder me?'24 After they have hanged him, the villains stab him repeatedly. Bel-Imperia calls out, 'Murder, murder, helpe Hieronimo, helpe'. Lorenzo orders his accomplices to 'stop her mouth: away with her' and Bel-Imperia is dragged offstage. Hieronimo, awakened by the commotion, enters after the murderers have scattered into the night. In the darkness he does not, at first, recognize the body. When he cuts him down he realizes, 'Alasse it is Horatio my sweete Sonne'. The entire sequence, from the appearance of the masked men to Hieronimo's identification of his dead son, occurs within a span of twenty-eight lines. The focus throughout is on four men brutally overpowering one, murdering him, and then mutilating his body. These actions are punctuated by Bel-Imperia begging for Horatio's life and crying for help. Only after Hieronimo enters is there anything like a pause as he expresses his feeling of dread at hearing a woman's cries in the middle of the night.

While characters do exit and enter, the arc of the action is in real time and within a single space. By returning to the early textual version and evoking the implications it has for performance, we can consider how an early modern viewer would have read this illustration. Kress and Van Leeuwen argue that reading visual narrative as if it were a version of verbal narrative 
replaced earlier forms of visual apprehension in the sixteenth century. They assert that the mode of visual reading that was replaced was that engendered by the triptych, in which reading proceeded from the centre to the margins of the image. ${ }^{25}$ While this may be the case with the elite images that Kress and Van Leeuwen focus on, the shift was slower to apply to popular print images, and in the early seventeenth century both forms can be said to apply to play-text title-page woodcuts. While narrative-based illustrations such as that for Philaster and A Maidenhead Well Lost clearly move from left to right, others including Doctor Faustus, Arden of Faversham, and Friar Bacon and Friar Bungay maintain a centre/margin composition, where the most important information is presented at the centre and the surrounding information is subservient to or supportive of the centre. The central element makes sense of the elements on either side of it, thus giving them their meaning and coherence. ${ }^{26}$ The Spanish Tragedy illustration, upon first examination, appears to be a frenzy of disorganized action, with Horatio's murder, Bel-Imperia's kidnap, and Hieronimo's discovery of his dead son all collapsed into one crowded frame. The characters even overlap in a manner that does not make sense if one compares the illustration solely to a textual analysis of the sequence. Hieronimo's left leg overlaps with Bel-Imperia's skirt and the smoke from his torch curls over the trellis from which Horatio hangs. Bel-Imperia and Hieronimo do not share the stage at this moment as stipulated in the play-text, and the light from Hieronimo's torch does not reveal Horatio while he is hanging in the arbour. Nevertheless, the image's details impose a link among the characters that re-establishes the triptych mode of information conveyance. By placing Hieronimo at the centre of the composition, as the mediator of everything happening around him, the artist reiterates the main theme of the play and reminds the viewer of a pivotal moment in the action.

A visual analysis of this illustration should also take into account the relative salience of the composition's elements. Hieronimo is given the highest degree of salience in the illustration. David Machin defines salience as when 'certain features in compositions are made to stand out, to draw our attention. Such figures will have the central symbolic value in the composition. These are the ones that credit more attention than others. ${ }^{27}$ With his full-bodied active pose, flaming torch and sword at the ready, Hieronimo possesses more salience than his dead son, the captive Bel-Imperia, or Lorenzo, who is only partially in the frame. The revenge invoked by Hieronimo is predicated on Horatio's death, and ultimately involves Bel-Imperia and Lorenzo when they 
act in Soliman and Perseda. Furthermore, the arrangement of figures and actions creates a sort of 'high sensory modality', in which the sensory truth criterion is 'based on the effect of pleasure (or un-pleasure) created by the visuals: the more the visual qualities of an image (or other form of visual) stir our feelings, the higher its sensory modality. ${ }^{28}$ This 'truth' of feeling offers information to two types of viewers: those who know the play are automatically drawn into the memory of its enactment, while those who do not know the play are compelled by the horrific, violent scene. In this composition, Hieronimo's discovery - the light he brings to nefarious dealings — defines the structure of the rest of the play. His body and face are turned toward the hanged figure of his son at the very moment of recognition. His back is to Bel-Imperia and to Lorenzo, whose crime Hieronimo spends the rest of the play striving to reveal. Hieronimo's central position also gives emphasis to Lorenzo's attempt to sneak away, dragging Bel-Imperia with him. The very denseness and the shocking nature of the scene make it a perfect candidate for reproduction as a promotional illustration of the printed play. In contrast, the more grisly culmination of the play, in which Hieronimo extracts his revenge, takes well over 200 lines to complete. The dénouement is much more complex in terms of exposition and resolution, making the sequence a less valuable choice for an artist in terms of visual narrative composition.

Another element of the Spanish Tragedy composition that has provoked much discussion among scholars concerns the speech ribbons unfolding from the mouths of Hieronimo, Bel-Imperia, and Lorenzo. There are several surviving examples of speech ribbons, or banderoles, associated with seventeenth-century printed drama. These range from the prophecies of the brazen head in Friar Bacon and Friar Bungay to the mournful protestations of the forsaken lover in The Vow Breaker. While banderoles may have gradually disappeared from many painting genres, they continued to be incorporated in printed drama through new editions of plays as well as freshly drawn illustrations. The title-page woodcut for The Witch of Edmonton was first published in 1658, and includes speech ribbons emanating from the mouths of Mother Sawyer and Dog, her familiar. In the case of The Spanish Tragedy, scholars debate the relationship of these speech ribbons to the text of the play and to performance, but also as an indicator of the illustration's artistic value in relation to other forms of drawing and painting at the time. The differences in The Spanish Tragedy are primarily a matter of condensing the speeches: 


$\begin{array}{ll}\text { Hieronimo (text) } & \text { Alasse it is Horatio my sweete Sonne } \\ \text { Hieronimo (woodcut) } & \text { Alas it is my son Horatio } \\ \text { Bel-Imperia (text) } & \text { Murder, murder : helpe Hieronimo, helpe } \\ \text { Bel-Imperia (woodcut) } & \text { Murder helpe Hieronimo } \\ \text { Lorenzo (text) } & \text { Come, stop her mouth : away with her } \\ \text { Lorenzo (woodcut) } & \text { Stop her mouth }\end{array}$

For critics of book illustration such as Edward Hodnett, these ribbons are yet another demonstration of English woodcarvers' technical naïveté and suggest a sort of sloppiness on the part of the artist or the publisher who commissioned the work. While it is possible that concessions were made to fit text into available space, or that the artists worked from incomplete or faulty textual source material that resulted in errors, it is also possible that the differences are a result of the artist relying on the dynamic nature of the play in performance. Syme defines the relationship between spoken and written speech in the Spanish Tragedy illustration as much closer than has previously been assumed. He demonstrates that the physical events of sight and sound in performance make sense of the speech ribbon text. Syme argues that the text in the banderoles serves as both 'originary text' and as an artistic facsimile of drama. As an originary text the lines are 'render[ed] faithfully, or as faithfully as an actor might. ${ }^{30}$ The dramatic quality of the banderoles is shown in the way they are placed in the illustration, 'broken up into parts, freed from the constraints of the orderly progression of the printed page, the characters' lines intermingle [and] demand space'. ${ }^{31}$ Paul Yachnin suggests that this representation of the human voice shifting from the stage to the page begins to make more sense when we distance ourselves from the modern separation of seeing and hearing as two distinct sensory processes - one based on the refraction of light and the other reliant on vibrations of air - and try to understand the two senses as a seventeenth-century English person would have done. 'People in Shakespeare's time tended to think of both as events that were physical in the same way and to the same degree. In both cases, some thing entered the portals of the body; writers in Shakespeare's time commonly took for granted the physicality or quasi-physicality of good or, more commonly, bad influences'. ${ }^{32}$ By positioning the effects of seeing and hearing more closely together in a way reminiscent of the time in question, the incorporation of what to us appear artificially imposed notations of speech becomes less problematic. 
Meyer Schapiro examines the relationship between image and text in medieval and renaissance painting, analyzing the ways in which artists and illustrators attempted to integrate action and speech in the visual plane. Schapiro sees banderole texts not as labels representing textual passages, but as simulated speech acts. He argues that 'Speech belongs to the speaker in a way different from the words on the adjoining text'. ${ }^{33}$ This incorporation of performative speech linked to the character gives it a primacy and an urgency that serves to enact the scene for the viewer in a way not provided by the text alone. Social semioticians further differentiate the speech act from the 'image act', which creates a distinct demand upon the viewer and establishes a relation between the viewer and the image. The type of relation is then signified by means other than speech — facial expressions, gestures, etc. The image 'wants' something from the viewer, 'to form a pseudo-social bond of a particular kind with the represented participant. ${ }^{34}$ In the case of The Spanish Tragedy, the speech balloons create an embedded dialogic message to viewers: they reinforce the visual elements of the illustration and the themes of the play-text, eliciting sympathy for Hieronimo and encouraging viewers to put aside their concerns about Hieronimo's dismissal of Christian forbearance in favour of personal vengeance. The condensed dialogue teaches the viewer how to respond. The ribbons can be read left to right or from centre to margin. Hieronimo's grief at his devastating discovery is either way the primary message. Bel-Imperia's cry for help is secondary; in the context of the play as written this plea is a result of the attack upon Horatio, but in the illustration it also aligns with her personal plight as her brother kidnaps her. Lorenzo's line, which in the play is a command to his accomplices early in the sequence, here loses its place and power. It is too late to keep Bel-Imperia quiet. Hieronimo has heard her, and Lorenzo's plot to ruin his rival and thus marry off his sister to the Portuguese prince is doomed.

The representation of speech and image acts using the convention of the banderole is also found in an unusual and affecting painting genre unique to the Elizabethan period, known as the 'revenge painting'. According to Marguerite Tassi, ${ }^{35}$ revenge paintings were particularly fashionable in Scotland. The most famous of these, and one which offers an intriguing thematic parallel to The Spanish Tragedy, is The Memorial of Lord Darnley (figure 2). Commissioned by the murdered Darnley's father, Lord Lennox, and painted in $1567 / 8$, the painting presents a multimodal visualization of Lennox's campaign to avenge his son's murder through manipulation of his grandson, the infant King James VI of Scotland. Darnley, estranged husband of 


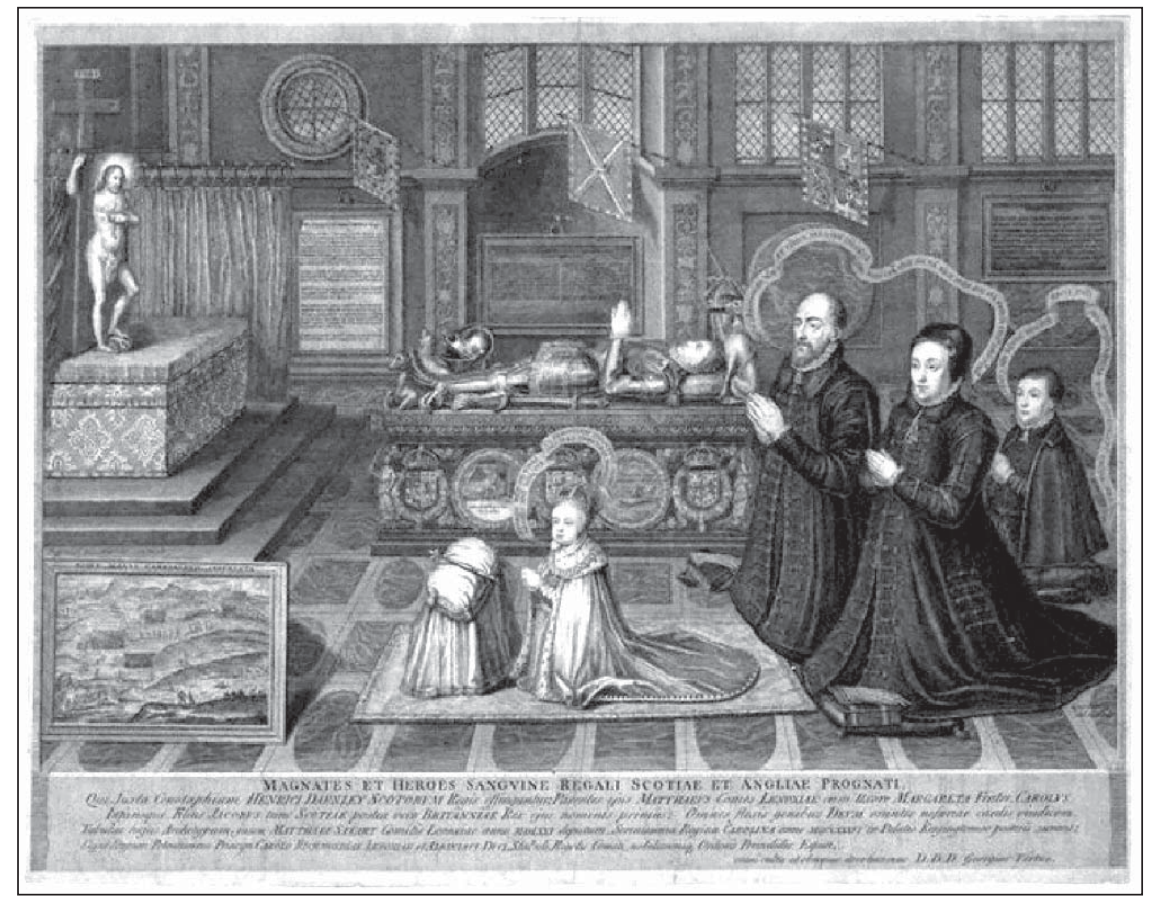

Fig. 2. George Vertue (after Livinus de Vogelaare). The Memorial of Lord Darnley. London, 1750. National Portrait Gallery website. 14 September 2009. Digital image. <http:// www.npg.org.uk/collections/search/portrait.php?linkID $=m p 01188 \&$ role $=s i t \& r N o=9>$.

Mary, Queen of Scots, died under mysterious circumstances ${ }^{36}$ and Lennox demanded that the queen and the cabal of Scottish lords suspected of his son's murder be brought to justice. The setting of the painting is a family chapel: Darnley's funeral effigy is at the centre, with the infant James praying at an altar below. To the left stands Christ leaning against the cross, and to the right kneel Darnley's father, mother, and brother. In addition to several pictorial and textual arguments presenting the case for revenge, speech ribbons unfurl from the mouths of the four living subjects. The most powerful of these emits from James's lips, 'Arise, O Lord, and avenge the innocent blood of the king my father and, I beseech you, defend me with your right hand'. ${ }^{37}$ Lennox was a kingmaker who had spent years cultivating his son as a favourite of Elizabeth and later as a suitable consort for Mary. His ambition to ensure his family's place in the line of succession, and more importantly to cement his role as the power behind the Scottish throne, was finally achieved 
after Mary was deposed and thirteen-month-old James was crowned. Lennox even served briefly as James's regent before he himself was murdered. The connection between this painting and The Spanish Tragedy lies in the employment of complex visual rhetoric devices to record personal tragedy and provide justification for the anticipated violent acts required to obtain justice. The use of banderoles in The Memorial of Lord Darnley emphasizes the importance of what Tassi calls a memento vindicta 'whose purpose is to incite the viewer and the patron-commissioner to action.' ${ }^{38}$ In the case of The Spanish Tragedy, the woodcut illustration with its speech ribbons offers the viewer the moment of personal tragedy. By tying the visualization of Horatio's murder to a scene later in the play, the Fourth Addition — also known as the Painters Part - the play provides a full-blown memento vindicta.

The Spanish Tragedy offers the spectator and reader a particularly powerful example of the sensory complexities of Elizabethan theatre. The visual and the performative are woven closely together and borne out in the multimodal nature of the woodcut illustration. This illustration may also be linked to the Painters Part, in which Hieronimo commissions the painter Bazardo to produce a sound- and speech-filled allegorical family portrait reminiscent of the revenge painting for Lord Darnley. As Hieronimo conveys what he wants Bazardo to paint, he effectively girds himself for the actions to come. As with Lennox and his commission of The Memorial of Lord Darnley, Hieronimo expects this painting not only to articulate the grief he suffers at the loss of his son but also to act as a public proclamation of his campaign of vengeance. The Fourth Addition is rife with distinctive synaesthetic descriptions that enhance the rhetorical power of Hieronimo's commission. The painting he envisions, which will celebrate his family while justifying his revenge, incorporates motion as well as sound, and even transcends time. As he instructs Bazardo about what should be included in the painting, Hieronimo begins with a traditional family portrait but quickly veers into terrain that is artistically problematic, if not impossible. As he recalls the night of Horatio's murder, Hieronimo invokes Nature at her most ominous: 'Let the clouds scowl, make the moon dark, the stars extinct, the winds blowing, the bells tolling, the owl shrieking, the toads croaking, the minutes jarring, and the clock striking twelve' (144-50). He describes Horatio's hanging body as 'tottering, and tottering as you know wind will weave a man' (148-9), a description that may drive the audience immediately back to the action of act 2 where the desperate father also attempts to visualize his devastating emotions. His command to 'Draw me like old Priam' (153) is a reasonable direc- 
tive: renaissance art is replete with early modern subjects posing as classical figures. Hieronimo's identification with the King of Troy, however, once again crosses the line from conventional artistic reproduction to externalized emotion: 'Make me curse, make me rave, make me cry, make me mad, make me well again, make me curse hell, invocate heaven, and in the end leave me in a trance' (154-7). Hieronimo's commission invokes powerful empathy in the modern reader and presumably would have done the same for a seventeenth-century reader or audience member. The actor portraying Hieronimo would have to employ significant physicality - the speech all but dictates Hieronimo's frantic movement about the stage as he tries to communicate what he envisions. The speech demonstrates the influence the actor can have upon the audience, providing the trigger for the spectator to 'see' and 'hear' what is described. In this moment Hieronimo has recreated and overwritten that murder scene, simultaneously destabilizing the play's narrative and reinforcing his sympathetic connection with the audience.

The painting that Hieronimo commissions is rhetorically powerful and yet technically improbable. His evocation of the genre of the revenge painting provides a possible artistic connection. In The Memorial of Lord Darnley, the family chapel provides the focal point for the father's revenge, offering the viewer heraldic proof of the dead man's abused honor and the righteous claim to Christian vengeance. There is even evidence that Lennox's campaign is effective: a scene inset at bottom left shows James leading his troops into battle with a banner invoking his father's murder, while Mary surrenders at Carberry Hill. In The Spanish Tragedy the revenge painting is never produced. In fact, neither Bazardo nor the painting receives further mention. Hieronimo will, rather, present a piece of performance art, turning his creative abilities to more effective use in writing and producing Soliman and Perseda, the play presented for the Spanish court that provides the instrument for achieving his revenge. The woodcut illustration accompanying the printed version of the play is not designed to replicate the rich appeal of a revenge painting, and yet it does provide some of the elements in miniature. It represents how immoral a state Spain has become, where petty jealousy leads to murder and men of honour are left to obtain justice through violence rather than the law. The title-page illustration, for readers as well as viewers of the play, forges a powerful link between the murder sequence in act 2 and the Fourth Addition. The viewer is reminded yet again of the sensory elements of the scenes: Horatio 'tottering' in the wind, Bel-Imperia crying for help, and Hieronimo discovering his son's dead body in the dark. The 
composition and incorporation of speech depiction in the woodcut make it, if not a revenge painting, certainly a powerful memento vindicta.

An opportunity to examine the Spanish Tragedy illustration in terms of its relationship to contemporary performance practice comes through identification of properties and dress in the woodcut. While the woodcut does not provide a straightforward documentation of stage elements, it may offer hints about how the play was staged at the time. As with other extant illustrated title pages of the period, the frame offered in the Spanish Tragedy illustration does not represent a theatrical space. Scenes from Arden of Faversham, Doctor Faustus, and Friar Bacon and Friar Bungay depict interior spaces. Scenes from Philaster, The Maid's Tragedy, and A King and No King depict more naturalistic exterior spaces. None of these is meant to suggest the scene on stage. The Spanish Tragedy illustration does not attempt to set the action outdoors but rather includes a unique, artificial element that may connect the illustration more closely with stage practice. This element is the embellished screen from which Horatio is hanged - rather than a more naturalistic tree or arbour one might expect from reading the text. The screen is a flimsylooking arched frame garnished with jagged leaf-like protuberances. If the artist had used the play-text as his source, the powerful emphasis on the words 'tree', 'arbour', and 'bower' throughout the play in both dialogue and stage direction would have influenced his vision. By the same argument, if the artist had first-hand experience of a production of the play, the use of a prop or set piece used to represent the arbour might equally have influenced him. An examination of the list of 'The Enventary tacken of all the properties for my Lord Admeralles men, the 10 of Marche 1598' catalogued by Philip Henslowe in his Diary reveals a variety of set pieces and props including ' $\mathrm{j}$ baye tree'. ${ }^{39}$ There is no description in the play that suggests a bay tree, and it cannot be determined if such a property would have been capable of such strenuous use in performance, considering that there are two on-stage hangings in the play. ${ }^{40}$ Nevertheless, the fact that prop trees were available to the Admiral's Men is significant. The play was associated with the troupe from at least 1597, when they performed two successful revivals. The inclusion of the bay tree in Henslowe's inventory also suggests that the playing company was accustomed to employing specific and elaborate set decoration when performing in London. ${ }^{41}$

It is unclear how this scene might have been portrayed on an early modern stage, but several scholars have contemplated the possibilities at length. J.R. 
Mulryne, in his edition of the play, writes in a footnote regarding the stage direction in 2.4, 'They hang him in the arbour':

Whether a stage-tree was used for this purpose remains unclear; Isabella (IV, ii, $60 \mathrm{ff}$.) seems to refer to a tree; Hieronimo says (IV, iv, 111) he found Horatio 'hanging on a tree'; the author of the Fourth Addition thinks very specifically of a tree (see $11.60 \mathrm{ff}$.). But editors may well be right in arguing that the arbour illustrated on the title-page of the 1615 edition (a trellis-work arch with a seat incorporated in it) may have been decorated with leaves and branches, and so have served as both arbour and tree. ${ }^{42}$

In a later footnote regarding the hanging of Pedringano in 3.6, Mulryne writes, 'The property which has already done duty as an arbour may have again been used here (stripped, perhaps, of its leaves and branches) to effect this second hanging. ${ }^{43}$ The trellis appears once more in 4.2, when Isabella tears the arbour apart in her final act of mad grief before stabbing herself. The stress on the set piece, as well as this violent stage destruction, would require a prefabricated and restorable property ready for the next performance. In this case, Mulryne suggests two alternatives: 'Isabella may merely strip the leaves and branches from the arbour, or she may topple a property tree if one was used'. ${ }^{44}$ If the woodcut illustration was patterned after a performance, the artist observed something akin to the former, an arched trellis rather than a property tree.

D.F. Rowan believes a contemporary staging of The Spanish Tragedy would have made maximum use of a free standing structure to identify a place of love and death in much the way modern productions do. He suggests that the trellis/arbour might have done triple duty as the gallows for Pedringano's execution and the reveal of Horatio's body at the play's climax. Rowan goes so far as to argue that the trellis was a major set piece remaining on-stage throughout the play, citing the woodcut as evidence: 'There was a property arbour on stage, and the pertinent questions are whether it remained on stage throughout the play, and where it was located on the stage ... Probably placed against the back wall when not in use, it was brought forward to the forestage when needed'. ${ }^{45}$ Rowan's advocacy for an omnipresent set piece identifies crucial interaction between all of the major characters in the play as well as most key plot points. In fact, all of the characters who die violently in the course of the play, with the possible exception of the Duke of Castile, interact in some way with this trellis. Here Horatio and Bel-Imperia hold 
their tryst; here Lorenzo, Balthazar, Pedringano, and Serberine murder Horatio; and here Pedringano is executed. Both Hieronimo and Isabella attack the tree - he verbally and she physically. If we accept Rowan's conclusion, there is a further and particularly profound irony in Hieronimo's relationship to the double gallows. The tree in his private orchard is the scene of his son's murder - an act that even the Knight Marshal of Spain is helpless to prevent. And yet Hieronimo is not unaware of the paradox inherent in Pedringano's execution by hanging and his own role in sentencing the villain to this form of execution. Still, he cannot bear to remain and watch the death penalty carried out: 'God forbid / A fault so foul should 'scape unpunished. / Despatch and see this execution done - / This makes me to remember thee, my son' (3.6.95-8).

The riveting nature of Horatio's death is not as strong on the page, primarily because it takes place between the lines. On stage, however, it would have been engrossing for the sheer spectacle it afforded and for the emotional associations it created for the audience. As Molly Smith argues, the constant reminders of Horatio's violent murder in both text and stage business throughout the play make it a much more resonant event than the framing device of Andrea's wrongful death. In fact, without his pointed interruptions in the main action, Andrea would be quickly forgotten. As Smith argues, 'Horatio's body, hanged and mutilated before a full house, thus takes precedence over Don Andrea, whose death has been narrated rather than witnessed'. 46 The powerful stage business of the hanging and desecration of Horatio's body leads me to question Alfred W. Pollard's conclusion that the hanged Horatio would have been represented by a dummy. Referring to the woodcut, Pollard assumed that the actor-victim would have been replaced at some point: 'I cannot resist remarking on how admirably he [the artist] has caught the pose of the straw dummy, which must have been left hanging to personate Horatio, in place of the actor, who had doubtless slipped behind the arbour during the scuffle and was now resting after his exertions. ${ }^{47}$ If the arbour/bower property were prominently visible on the stage, such a switch would clearly have undermined the shock value of watching the murder and discovery enacted. Performing the hanging of a character with harness and hook is not difficult; an actor could easily have remained dangling from the set piece for the length of time required for Hieronimo to enter, recognize him, and haul him down. Andrew Gurr states that this type of business was a 'standard shock device' at this time, wherein a hook attached to a band tied under the actor's armpits would have satisfied the illusion. ${ }^{48}$ This visceral 
quality of the scene as staged makes it visually powerful for the illustration in the printed play.

The appearance of Hieronimo in the illustration offers a second, smaller but equally interesting, connection between the play-text and stage performance. Upon hearing Bel-Imperia's cries for help he enters 'in his shirt. ${ }^{49}$ In the woodcut, he wears a loose-fitting, rumpled shirt and ballooning trousers, plus some sort of cap and soft shoes - perhaps a nightcap and slippers. The addition of hastily thrown on trousers and slippers would support the representation of the poor old man being summoned from bed, as the other three characters are fully dressed. More significantly in terms of symbolism, Hieronimo carries both a sword and a lighted torch. The stage directions for act 2 do not specify that he carry these items. As a homeowner awakened in the middle of the night by fearful cries, it makes sense that he would thus arm himself and light his way. A useful confirmation of these items comes in the Fourth Addition, when Hieronimo dictates the discovery of his son to the painter: 'after some violent noise, bring me forth in my shirt, and my gown under mine arm, with my torch in my hand, and my sword reared up thus: and with these words: What noise is this? who calls Hieronimo?' (135-9). This elaboration on his appearance and slight reworking of his line from act 2 may well provide the source for the woodcut artist's interpretation of his appearance. The torch also provides an indication of contemporary public theatre stage practice in which torches, lanterns, and candles were used to suggest night scenes. ${ }^{50}$ The Fourth Addition contains repeated references in the dialogue to torches lighting up the night, culminating in this ironic exchange between Hieronimo and his servant Pedro:

Hieronimo What make you with your torches in the dark?

Pedro You bid us light them, and attend you here.

Hieronimo No, no, you are deceived, not I, you are deceived:

Was I so mad to bid you light your torches now?

Light me your torches at the mid of noon,

Whenas the sun-god rides in all his glory:

Light me your torches then.

Pedro Then we burn daylight.

Hieronimo Let it be burnt: night is a murderous slut,

That would not have her treasons to be seen.

Considering that the first edition to which the woodcut was attached was printed in 1615, some thirteen years after the Painter's scene was added, the 
artist who drew the scene for the title-page illustration may have incorporated Hieronimo's description of his actions from the Fourth Addition into the action of the woodcut. In addition, and within the realm of our understanding of contemporary stage practices, the inclusion of the lighted torch may have represented the performed moment of Hieronimo's discovery of Horatio's dead body. Michael Hattaway emphasizes the double meaning of the torch in this context: 'Entrances in particular often established an informing image for the ensuing scene. Stock properties such as torches had two functions when carried on to the stage: to reveal to the audience that the action is taking place by night, but also to suggest that the bearer is in the dark, uncognizant of his fate. ${ }^{51}$ Martin White pins the double meaning of a torch to an earlier point in the scene, when the mood is still romantic: 'An Elizabethan audience would undoubtedly have noted the irony of invoking darkness, invariably associated with danger and evil, at the beginning of what promises to be a love scene. ${ }^{52}$

Further examination of the clothing worn by the other figures in the illustration yields more clues about performance. Bel-Imperia wears an intricately decorated lady's gown, defining her station. On top of her head is some sort of headpiece or mantilla, perhaps suggestive of Spanish style. The clothing of Lorenzo and Horatio is most interesting and, to the best of my knowledge, has not been considered in terms of characterization. Horatio is booted and spurred, wearing a military-style jerkin. Overall his clothes are simple and functional, suitable for a warrior. Lorenzo, on the other hand, is reminiscent of a louche Jacobean court figure, resplendent in a tall brimmed hat with plume, finely decorated sleeves, gartered breeches, and shoes topped with rosettes. He also wears a full-faced black mask. ${ }^{53}$ R.A. Foakes glosses over the difference between the costumes; ${ }^{54}$ however, there is no reason not to think of these details as efforts on the part of the artist to capture identifying traits that clarify the difference between these two young men on stage. David Machin calls this 'categorisation', wherein '[p]eople can be represented with attributes that connote stereotyped characteristics. These attributes can be cultural ... [b]ut over time they become a kind of "common sense", which still lives on, especially in apparently innocent entertainment media. 55 This contrast in costume style belies the extreme opposite positions defined by these two characters. Horatio, as Don Andrea's friend and 'second', is a brave and upstanding military hero, whereas Lorenzo is a dissipated, self-serving manipulator who craves the power and materialistic rewards of court. Despite Horatio's decency and heroism, in the world of Spain he can never be equal to 
the amoral, aristocratic Lorenzo. While the king does acknowledge Horatio's bravery in the victory over Portugal, he clearly favours Lorenzo. A perusal of the inventories in Henslowe's diary reveals a wide array of costume pieces that would have been appropriate for both characters: a 'Spanerd gyrcken' or a 'read Spanes dublett styched' and many richly embroidered 'satten dublets ${ }^{56}$ would have assisted in defining both characters in the eyes of audience members. These two modes of dress - the simplicity of the soldier and the foppery of the courtier - serve to further instantiate in a viewer's mind the waste of Horatio's death and the upside-down nature of Spain.

The Spanish Tragedy was a particularly popular dramatic work with a long history of success in the over fifty years from its first performances to the closing of the theatres in 1642. During that period the play saw untold productions in London and on tour, and at least eleven print editions. The woodcut illustration featured on the play's title page beginning in 1615 offers the modern scholar an interesting perspective on how publishers communicated with their customers. Such title pages provided the basis for a complex interaction that extended beyond the immediate exchange between bookseller and book buyer to include the theatre-going public and potentially a much wider swath of the London population. Illustrated title pages such as that for The Spanish Tragedy offered a compelling distillation of the play's action and themes that served as a powerful marketing tool, whether at the point of sale as the visible cover of the quarto or nailed to a post as a promotional one-sheet. The Spanish Tragedy illustration is especially valuable as it presents an artistic interpretation of the climactic sequence in the play that would have been particularly resonant for an early modern viewer, whether that viewer had seen the play on stage, read the text, or was familiar with the story by means of peripheral materials such as ballads. The fact that the composition of the illustration veers from the action as strictly delineated in the play-text should not deter us from evaluating it in terms of its relationship to the play. Rather, we need to seek out new means of analyzing the material in hopes of making better sense of the illustration, both in conjunction with the title page and as a multimodal message in its own right with significant value to an early modern viewer.

Social semiotics provides one such means for re-examination. By employing the tools of visual rhetoric we can unpack the illustration for the Spanish Tragedy title-page and begin to reclaim it in terms of its significance as a valid representation of the play. It is then possible to examine the elements of the composition and make more informed determinations about what the 
illustration is communicating. Rather than a haphazard and crudely drawn sketch, we begin to see the scene as an artefact of the play. Certainly Hieronimo, in his central position with his illuminating torch, provides the key to understanding the play, in terms of the link between image and the text in the title. He is the character identified as central to the audience. The artist has taken care to compose the illustration in such a way that the viewer's eye is always drawn back to Hieronimo. The information presented on the left and right margins supports and reinforces the tragedy and the root of Hieronimo's quest for vengeance. The condensed dialogue in the speech balloons also serves to reinforce the bond between viewer and image. These banderoles create a demand upon the viewer that encourages an emotional reaction, instilling a feeling of compassion and sympathy for the protagonist.

This approach also allows us to reconsider the question of the illustration's connection to early modern theatrical practice. This scene is not meant to provide a snapshot of the play on stage. The fluid action of the sequence, however, connects the woodcut more closely to performance than to the text. Specifically, the incorporation of what appear to be set pieces and props, as well as the suggestion of costumes, strengthens the relationship between the illustration and the play as it might have been performed. The artist took care to identify the four characters by their distinct clothing styles, some of which is indicated in dialogue but most of which would have been worked out by the acting companies relying upon their costume stores. The torch and sword are also mentioned in the text, but the torch would have held particular resonance for a contemporary theatrical audience - encoded with the signifiers for a night scene played in the afternoon, but also providing cues to the viewer about the ominous nature of the scene and the moment of revelation for Hieronimo. Most intriguing is the presence of a trellis-type structure that bears the hanging body of Horatio. The significant detail afforded this element suggests its importance to the artist. Again, composition drawn solely from the text would more likely result in a naturalistic tree, arbour, or bower - the words used to describe the site in the text. This piece is curiously artificial looking, and suggests that the artist drew, at least in part, from an experience watching the play performed.

Because analysis of images in printed texts in the period has normally been thematic and iconographic, the formal approaches used in visual rhetoric expand upon what we already know about how and what these images communicate, and enlarge our understanding of them and their importance. In the process, we may begin to discover new pathways of understanding 
why and when such illustrations were employed by publishers to sell plays. Such case studies as this one for The Spanish Tragedy make it possible to reveal hitherto unrecognized clues about early modern drama in print and on stage.

\section{Notes}

1 Thomas Kyd, The Spanish Tragedy, ed. Andrew Gurr (London, 2009). All quotations from the play except where indicated are taken from Gurr's edition. In special instances, quotations are from The Spanish tragedie: or, Hieronimo is mad againe Containing the lamentable end of Don Horatio, and Belimperia; with the pittifull death of Hieronimo, (London, 1623), ЕEBO.

2 The dating of the play has not been confirmed, but most scholars place the first performances at some point in the 1580s. Chambers tentatively dates them at 1589 (3:396), while J.R. Mulryne cites Tom McAlindon and Arthur Freeman as proposing a date around the middle of the decade to reflect what Freeman calls the play's 'pre-Armada tone'. See Thomas Kyd, The Spanish Tragedy, ed. J.R. Mulryne (New York, 1989). In particular, see Mulryne's section on 'Authorship and Date', xiiixiv.

3 D.F. Rowan, 'The Staging of The Spanish Tragedy', G.R. Hibbard (ed.), The Elizabethan Theatre V: Papers Given at the Fifth International Congress on Elizabethan Theatre Held at the University of Waterloo, Ontario, in July 1973 (Hamden CT, 1975), 113.

4 Gurr, Spanish Tragedy, xviii.

5 Mulryne, Spanish Tragedy, xxxi.

6 These were prominently announced on the title page: 'Newly Corrected, Amended, and Enlarged with new Additions, as it hath of late been diuers times Acted'.

7 These editions appeared in 1618, 1623 (twice), and 1633. The version of the title page examined for this essay was printed by Augustine Mathewes for the third edition in 1623; while imprint information changed, the title, performance reference, and illustration remained the same on all editions from 1615 until 1633.

8 For the purposes of this article I will rely on Gunther Kress and Theo Van Leeuwen, Reading Images: The Grammar of Visual Design, 2nd ed. (London, 2006) as well as David Machin, Introduction to Multimodal Analysis (Oxford, 2007).

9 Alfred W. Pollard, 'Woodcuts in English Plays Printed Before 1660', The Library 2.1 (1899), 73. 
10 Edward Hodnett, Five Centuries of English Book Illustration (London, 1988), 46. Hodnett's loaded statement offers a left-handed compliment to The Spanish Tragedy and Doctor Faustus. They may offer the modern critic the best examples of the form, but in his opinion they confirm yet again that English draftsmen and woodcarvers were technically deficient in comparison with those on the continent.

11 Edward Hodnett, Image and Text: Studies in the Illustrations of English Literature (London, 1982), 19.

12 Thomas Heywood's biographical play about Elizabeth I appeared in two parts, in twelve editions between 1605 and 1639, ten of which featured a woodcut portrait of the queen.

13 Much, however, can be learned through cross-referencing Alan B. Farmer and Zachary Lesser's DEEP: Database of Early English Playbooks <http://deep.sas.upenn. edu> with W.W. Greg's Bibliography of the English Printed Drama to the Restoration (London, 1939).

14 Such copying, as in the case of the 1663 edition of Doctor Faustus, was probably due to the woodblock breaking or wearing out over time.

15 Jay Bolter and Richard Grusin, Remediation: Understanding New Media (Cambridge MA, 1997), 19.

16 Kress and Van Leeuwen, Reading Images, 114. Emphasis in original.

17 Peter Blayney, 'The Publication of Playbooks', John D. Cox, David Scott Kastan, and Stephen Greenblatt (eds), New History of Early English Drama (New York, 1997), 414, argues that 'books as slim as most play quartos would usually be sold without bindings'.

18 For a thorough examination of how printed title pages were used as advertising materials in early modern London, see Tiffany Stern, "'On each Wall and Corner Poast”: Playbills, Title-pages, and Advertising in Early Modern London', English Literary Renaissance 36 (2006), 57-89.

19 Kress and Van Leeuwen, Reading Images, 114.

20 The ballad is entitled The Spanish tragedy, containing the lamentable murders of Horatio and Bellimperia: with the pitifull death of old Hieronimo. To the tune of Queene Dido (London, 1620), ЕЕво. It includes the woodcut in the upper left corner of the sheet. Narrated by (a dead) Hieronimo, the ballad is faithful to the narrative of the play, with only a glancing reference to Andrea as Bel-Imperia's former lover and with no mention of the Portuguese subplot. Interestingly, while Hieronimo tells of the love between Horatio and Bel-Imperia and their meeting in the bower, there is no specific description of Horatio's murder.

21 Stern, “"On each Wall and Corner Poast”, 80. 
22 Holger Schott Syme, 'The Look of Speech', Textual Cultures: Text, Contexts, Interpretation 2 (2007), 55.

23 Kress and Van Leeuwen in Reading Images, 175-200, provide a thorough analysis of the meaning of composition as regards multimodal text. They distinguish the information value of left and right (Given and New), top and bottom (Ideal and Real), and centre and margin, which can combine both Given and New with Ideal and Real values, in particular by means of a triptych layout where the centre position 'mediates' the information in the margins.

24 The quotations from this sequence occur on sig. D2 of the 1623 edition of the play.

25 Kress and Van Leeuwen, Reading Images, 197-8.

26 Ibid, 194-9; also David Machin, Introduction to Multimodal Analysis, 147.

27 Machin, Introduction to Multimodal Analysis, 130.

28 Ibid, 61.

29 To best demonstrate the state of these three lines in text and image, I have cited the 1623 edition of the play.

30 Syme, 'The Look of Speech', 56, emphasis added.

31 Ibid.

32 See Paul Yachnin, 'Eye to Eye Opposed', in Anthony B. Dawson and Paul Yachnin, The Culture of Playgoing in Shakespeare's England: A Collaborative Debate (Cambridge, 2001), 73, emphasis in original.

33 Meyer Schapiro, Words, Script, and Pictures: Semiotics of Visual Language (New York, 1996), 118. While Schapiro's work focuses primarily on medieval and early renaissance religious art rather than illustrations associated with printed drama, it does provide a forum for examining the speech ribbon as used in play-text illustrations.

34 Kress and Van Leeuwen, Reading Images, 118.

35 Marguerite Tassi, The Scandal of Images: Iconoclasm, Eroticism, and Painting in Early Modern English Drama (Selinsgrove, 2005).

36 Darnley was staying in Edinburgh at separate lodgings from the queen; a massive explosion in the house during the middle of the night appeared to be the cause of his death (along with that of his valet), but closer examination of the bodies revealed that they had been strangled. It was suspected by Lennox and others that the explosion was in reality a cover-up for the murder. See Alan Stewart, The Cradle King: the Life of James VI \& I, the First Monarch of a United Great Britain (New York, 2003), for more on the machinations of Mary's reign in Scotland, the upshot of Darnley's murder, and the tumultuous upbringing of James.

37 Tassi, The Scandal of Images, 172-3.

38 Ibid, 171. 
39 See 'Playhouse Inventories Now Lost' from R.A. Foakes (ed.), Henslowe's Diary, 2nd ed. (Cambridge, 2002), 316-25. The reference to the bay tree is on 319.

40 Pedringano's hanging in 3.6 also takes place in full view of the audience.

41 We know that in 1598 the Admiral's Men were performing at Henslowe's Rose Theatre, so the 'baye tree' in his inventory would have been available to them if they required it.

42 Mulryne, The Spanish Tragedy, 43.

43 Ibid, 69.

44 Ibid, 110.

45 Rowan, 'The Staging of The Spanish Tragedy', 120.

46 Molly Smith, 'The Theater and the Scaffold: Death as Spectacle in The Spanish Tragedy', Studies in English Literature, 1500-1900 32 (1992), 225.

47 Pollard, 'Woodcuts in English Plays', 75.

48 Gurr, The Spanish Tragedy, xvii.

49 Ibid, 43. Gurr identifies the shirt as a nightshirt, citing Hieronimo's description of his attire in the Fourth Addition 11. 135-9 as basis for probable stage practice.

50 See Hugh M. Richmond, Shakespeare's Theatre: A Dictionary of his Stage Context (London, 2002) in the entry for 'night', 314: 'Despite the lack of appropriate lighting effects in producing plays on an open-air stage in the afternoon, there are many night scenes in Shakespeare, usually carefully signposted by allusions to the time of day, by mention of torches and torch-bearers, candles, lanterns, moon and stars. Darkness is also indicated by costume through the wearing of nightgowns and nightcaps'.

51 Michael Hattaway, Elizabethan Popular Theatre: Plays in Performance (London, 1982), 65.

52 Martin White, Renaissance Drama in Action: An Introduction to Aspects of Theatre Practice and Performance (London, 1998), 135. White uses Spanish Tragedy 2.4 as a compelling case study for the performance of outdoor space, 109-43.

53 Although dictated in the script, this mask seems pointless, as Bel-Imperia immediately recognizes her brother and Balthazar.

54 In Illustrations of the English Stage, 1580-1642, 104-6, Foakes does express surprise at Horatio wearing boots and spurs and is puzzled by the rosettes on Lorenzo's shoes. The author does not elaborate as to why this footwear confuses him.

55 Machin, Introduction to Multimodal Analysis, 122.

56 See the list of costume pieces in 'Playhouse Inventories Now Lost' from Foakes, Henslowe's Diary, 317-23. 